\title{
An Overview of Stress-Induced Resveratrol Synthesis in Grapes: Perspectives for Resveratrol-Enriched Grape Products
}

\author{
Md. Mohidul Hasan and Hanhong Bae * \\ Department of Biotechnology, Yeungnam University, Gyeongsan 38541, Korea; mhasan@hstu.ac.bd \\ * Correspondence: hanhongbae@ynu.ac.kr; Tel.: +82-53-810-3031 \\ Academic Editor: Thomas J. Schmidt \\ Received: 15 December 2016; Accepted: 9 February 2017; Published: 14 February 2017
}

\begin{abstract}
Resveratrol is the most important stilbene phytoalexin synthesized naturally or induced in plants, as a part of their defense mechanism. Grapes and their derivative products, including juice and wine, are the most important natural sources of resveratrol, consisting of notably higher amounts than other natural sources like peanuts. Consumption of red wine with its presence of resveratrol explained the "French Paradox". Hence, the demand of resveratrol from grapes is increasing. Moreover, as a natural source of resveratrol, grapes became very important in the nutraceutical industry for their benefits to human health. The accumulation of resveratrol in grape skin, juice, and wine has been found to be induced by the external stimuli: microbial infection, ultrasonication (US) treatment, light-emitting diode (LED), ultra violet (UV) irradiation, elicitors or signaling compounds, macronutrients, and fungicides. Phenylalanine ammonia lyase, cinnamate-4-hydroxylase, coumaroyl-CoA ligase, and stilbene synthase play a key role in the synthesis of resveratrol. The up-regulation of those genes have the positive relationship with the elicited accumulation of resveratrol. In this review, we encapsulate the effect of different external stimuli (biotic and abiotic stresses or signaling compounds) in order to obtain the maximum accumulation of resveratrol in grape skin, leaves, juice, wine, and cell cultures.
\end{abstract}

Keywords: resveratrol; grape; juice; wine; external stimuli; elicitation; nutraceutical

\section{Introduction}

Consumers are very conscious and interested in their good health through controlling their diet. Their concerns are increasing due to adverse diet-related health conditions including obesity, diabetes, cardiovascular diseases, and the consequent social and economic costs [1]. Food and beverages containing phenolics have enormous health benefits, including protection against cardiovascular diseases and different types of cancer [2]. Grapes, commonly consumed fruits, contain significant amounts of phenolic compounds: stilbene, flavonols, proanthocyanidins, and anthocyanins, known to be highly effective against cardiovascular diseases [3]. Resveratrol is a stilbene compound that became more popular after the discovery of its anticancer potential, limiting tumor initiation and progression in cancer-induced rats [4]. Resveratrol was also found to induce resistance in plants against microbial infection and extend the life span in different organisms, including yeast and vertebrates $[5,6]$. Furthermore, phytoalexin resveratrol is a secondary metabolite related to plant defense, elicited on the infection with pathogens or due to other external stimuli.

Resveratrol is a polyphenol that is widely studied for its nutritional and medicinal value. The effects of different biotic and abiotic agents on the induced synthesis of resveratrol in plant tissues have also been studied widely. Resveratrol biosynthesis occurs via the phenylalanine pathway, where phenylalanine ammonia lyase $(P A L)$, cinnamate-4-hydroxylase $(C 4 H)$, coumaroyl-CoA ligase 
$(4 C L)$, and stilbene synthase (STS) play a core role in the synthesis (Figure 1). The end product is synthesized as trans form, which may isomerize to cis form or even transformed to trans and cis-piceid due to resveratrol 3-O-beta-glycosyltransferases (O-3-GT) [7]. $p$-coumaroyl-CoA is a product of $P A L$, which is abundant in plants and used as a precursor for the synthesis of both resveratrol and chalcone. Therefore, in stilbene-synthesizing plants, STS competes with chalcone synthase (CHS) for the synthesis of resveratrol [8]. Furthermore, stilbene synthesis pathway is the side chain of phenylpropanoid pathway, which also can be treated as an extension of the flavonoid pathway [9]. A transcriptional factor, Myb14, has been found to regulate the expression of STS [10].

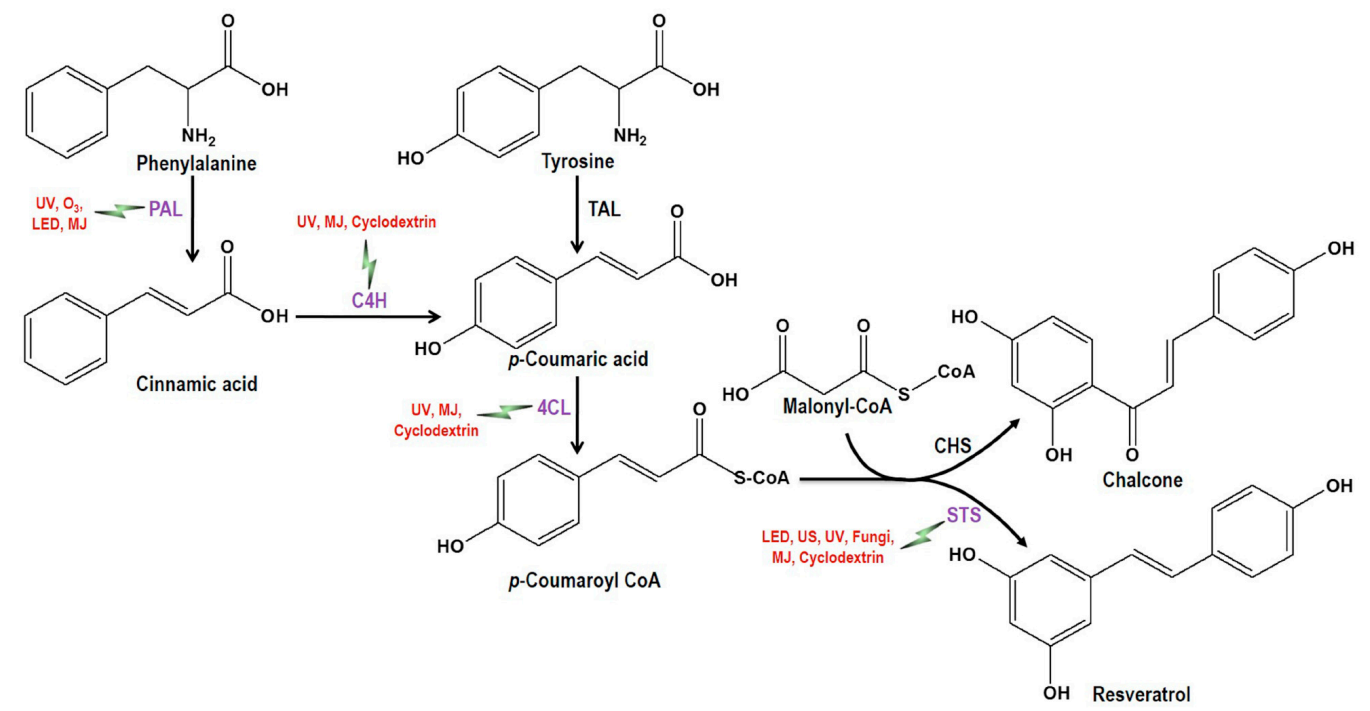

Figure 1. Biosynthesis pathway to resveratrol with enzymes involved and factors eliciting or inducing resveratrol synthesis (the symbol indicates [-] the induction of the corresponding enzymes by the mentioned elicitors or inducer). PAL, Phenylalanine ammonia lyase; $C 4 H$, Cinnamate-4-hydroxylase; $4 C L$, Coumaroyl-CoA ligase; TAL, Tyrosine ammonia-lyase; CHS, Chalcone synthase; STS, Stilbene synthase; UV, Ultra violet; US, Ultrasonication; LED, Light-emitting diode; $\mathrm{O}_{3}$, Ozone; $\mathrm{MJ}=$ Methyl jasmonate.

The accumulation of resveratrol in grapes varies with the grape cultivar, genotype, location, environmental conditions, and growing season. Varying amounts of resveratrol have been reported in grape skin, seed, stem, shoot, bud, root, and leaf [11,12]. However, relatively higher amount of resveratrol can found in grape skin, whereas, less in grape juice and wine.

The global demand of resveratrol is increasing, but natural synthesis and accumulation of resveratrol are very low in grapes. Therefore, continuous efforts are ongoing to induce the accumulation of resveratrol in grape skin. Resveratrol can be induced in grapes by both biotic and abiotic factors, including fungi [13-15], UV-C irradiation, jasmonic acid (JA), salicylic acid (SA), $\mathrm{H}_{2} \mathrm{O}_{2}$, and $\mathrm{AlCl}_{3}$ [16-19].

Naturally, resveratrol is recovered from few plant species, including grapes. Therefore, grape and grape processed products can be considered the most relevant sources for natural as well as enhanced production of this compound. Resveratrol has been used in the nutraceutical industry and also as an anticancer and anti-aging agent. Thus, it will be worth studying the maximum induction of this compound in grapes using single or combined external stimuli. Therefore, our studies summarize the effect of different biotic and abiotic stimuli on the induction of the resveratrol accumulation in grapes. We have also summarized the effect of different external stimuli on the biosynthesis of resveratrol, regulated through an enzymatic reaction.

\section{Elicitation of Resveratrol Due to Pathogen Infection}

Usually, stilbenes are constitutively present in all parts of the grape plant but can be elicited especially in leaves and fruits. Resveratrol is found to be directly involved in vine resistance against 
some plant pathogens including Botrytis cinerea [20-22], Plasmopara viticola [13], Rhizopus stolonifer [23], and Uncinula necator [24].

In the early stages of resveratrol research, accumulation of resveratrol was detected only in injured, UV-treated, or fungi-infected leaf tissues [25]. A considerably increased amount of resveratrol (3-fold) was found around the infected leaf area of $B$. cinerea. However, the accumulated resveratrol disappeared as the disease advanced further [20-22]. The localized accumulation of resveratrol might help to restrict the spread of $B$. cinerea infection until the environmental conditions are unfavorable for the pathogen [22]. The presence of significant amounts of resveratrol, prior to any visible lesions in fruits, proved that the phytoalexin elicitation initiated just after recognition of the pathogen by the plant [22].

Resveratrol, in its glycosylated form, was found in higher amounts than free resveratrol in grape juice and grape skin, irrespective of the degree of B. cinerea infection [26]. In another study, a significantly high amount of trans-resveratrol was induced by the 2nd day of $B$. cinerea infection, followed by the rapid decline in the levels by the 5th day after infection $[27,28]$. Surprisingly, a lower concentration of resveratrol was found in wine made from botrytized grapes, as compared to the wine from healthy grapes in Germany, while slightly higher resveratrol was reported in Hungarian wines prepared from B. cinerea infected grapes than those from healthy grapes [29]. Recently, 4-5 times induced accumulation of resveratrol in leaves, shoots, and flowers, was noted in the blooming stage, following three days after B. cinerea inoculation [30] (Table 1).

Induction of resveratrol in response of $B$. cinerea is a commonly studied phenomenon. However, other fungi are also known to induce the accumulation of this compound in grapes. P. viticola infected grapes accumulated 5 times more resveratrol than healthy grapes, and the accumulation increased with the degree of infection [13]. Infection with $U$. necator resulted in 12 times higher accumulation of resveratrol in grape skin [14]. Unlike B. cinerea, P. viticola and U. necator cannot detoxify or degrade resveratrol. Hence, they are unable to suppress the production of phytoalexin in Vitis spp. [14]. R. stolonifer was also found to induce 4 to 8.5 times accumulation of resveratrol in grapes after $24 \mathrm{~h}$ of incubation. However, subsequent incubation resulted in gradual degradation of the accumulated resveratrol [23]. Application of mannitol, followed by supplementation of methanolic extracts of Fusarium oxysporum in a two-stage Vitis vinifera cell culture system, significantly elicited the accumulation of resveratrol [31]. A soil bacterium belonging to Bacillus genus, applied along with Botrytis conidia, was found to elicit 16 times higher accumulation of resveratrol in grape leaves, as compared to the control [27] (Table 1). In response to the pathogen attack, pathogenesis-related protein- phytoalexins noted to be synthesized in plants as a part of defense mechanism [32]. However, the underlying mechanism for the increased accumulation of resveratrol showed up-regulated expression of the STS gene in response to B. cinerea and P. viticola inoculation $[15,33]$.

\section{Accumulation of Resveratrol in Response to Light}

Light is a vital element for photosynthesis of plants, ultimately affecting their growth and development, organogenesis, and production of primary and secondary metabolites [34]. Accumulation of secondary metabolites in plants, including stilbene phytoalexins, flavonoids, and carotenoids is also dependent on light $[35,36]$ and could be enhanced by the effect of light [36-39].

LEDs as are now commonly being used as a light source in the regulation of plant growth, photomorphogenesis, enhancing quality, and production of secondary metabolites [34,40]. A recent study involving the exposure of two grape varieties, "Campbell Early" and "Kyoho", to different light sources, showed that exposure to blue and red light caused enhanced accumulation of resveratrol in grape skin, as compared to white and purple light [41]. Blue, white, and purple light were found to increase resveratrol in Campbell Early by 8.4, 3.2, and 2.3 times, respectively, relative to the control. Similar increased accumulation of resveratrol was also found in "Kyoho" by 3.4, 3.1, and 2.1 times higher than the control with blue, white, and purple light, respectively [41] (Table 1).

Resveratrol synthesis by phenylpropanoid pathway and the induced expression of $P A L, C H S, C H I$, STS1, and STS2 was observed by irradiation with different light sources [41]. The maximum increase 
in mRNA of PAL and STS1 was observed after $24 \mathrm{~h}$ exposure to various light sources in Campbell Early, and the highest up-regulation of the genes was observed in response to blue light-irradiated berries [41]. In contrast, highly up-regulated expression of PAL and STS1 was observed in 'Kyoho' grape berries irradiated with red light and picked after $48 \mathrm{~h}$ of treatment [41]. Light-dependent regulation of $P A L$ and STS, the vital enzymes in the stilbene biosynthesis pathway, has also been reported previously $[12,15,42]$.

\section{Induced Accumulation of Resveratrol Due to Ultrasonication}

Ultrasonic cleaners are used to clean a wide variety of objects by applying high-frequency sound waves to agitate materials suspended in liquids. Ultrasonic cleaners have already been designed to clean and sterilize contaminants in harvested fruits and vegetables [43]. Additionally, this technique is also applied to enhance the accumulation of secondary metabolites in plants [44]. Previously, resveratrol was found to be increased by 8-143 times over control in whole or sliced peanut kernels after ultrasonication treatment $[37,45,46]$.

Hasan et al. applied the ultrasonication technique for the first time to increase the accumulation of resveratrol in grape skins and leaves [44]. The resveratrol accumulation was found to be increased in grape skin by 7.7 folds, after treatment with 5 min ultrasonication treatment, followed by $6 \mathrm{~h}$ incubation. However, the increase of resveratrol in leaves was quite less than that in grape skin. The amount of increased resveratrol in grape leaves after $15 \mathrm{~min}$ of ultrasonication, followed by $3 \mathrm{~h}$ incubation, was 1.8 fold higher than that observed in non-treated control [44] (Table 1). The accumulation of resveratrol in both grape skin and leaves was dependent on the ultrasonication time and the incubation period. A similar trend of resveratrol accumulation was shown in ultrasonication-treated peanut kernels, where $24 \mathrm{~h}$ of incubation resulted in higher accumulation, followed by a decrease with subsequent incubation [45].

Resveratrol-enriched grape juice was also prepared using the most effective ultrasonication treatment reported in previous work [47]. In all the grape varieties used, significantly higher elicited amount of resveratrol was found in grape juice manufactured from fruit treated with ultrasonication for $5 \mathrm{~min}$, followed by $6 \mathrm{~h}$ of incubation [47]. Ultrasonication treatment of grape skins of Campbell Early, MBA, and Kyoho increased the resveratrol in grape juices by 1.53, 1.15, and 1.24 times, respectively [47] (Table 1).

The induction of plant secondary metabolites by ultrasonication might be due to mechanical stress, along with micro-streaming caused by acoustic cavitation [48]. It is hypothesized that ultrasonication worked through increased mass transport due to the effects of cavitations, resulting in quicker product dispersal from the enzymatic production site [49]. Semi-quantitative RT-PCR showed an increased expression level of $R S$ in response to the ultrasonication treatment, where highest expression of STS was observed in grape skins treated with $5 \mathrm{~min}$ ultrasonication, followed by all subsequent incubation times up to $12 \mathrm{~h}$ [44]. However, in grape leaves, increased expression of STS was found only in $15 \mathrm{~min}$ of ultrasonication without further incubation, but increased after $3 \mathrm{~h}$ incubation, synchronizing with the observed highest accumulation of resveratrol in leaves with 15 min ultrasonication followed by $3 \mathrm{~h}$ incubation [44]. Phenylalanine ammonia-lyase $(P A L)$ activity in response to ultrasonication treatment might also be responsible for increased accumulation of resveratrol. A dramatic increase in the PAL enzymatic activity was observed in Panax ginseng cells due to the ultrasonication treatment [50], which is accountable for deamination of phenylalanine coumaryl CoA, the precursor of resveratrol biosynthesis [51].

\section{Accumulation of Resveratrol Due to Signaling Chemicals}

Among the stilbenes, resveratrol is the prime phytoalexin in plants, produced in response to external stimuli including UV and different signaling chemicals. For the induction of plant secondary metabolites related to the plant defense system, JA plays a key role in the signal transduction pathway [52,53]. 
Notable induction of stilbene accumulation with the addition of methyl jasmonate (MJ; the JA derivative) at day 6 after starting the culture was reported [54]. MJ was found to cause a 3-fold elicitation of trans-resveratrol, following $18 \mathrm{~h}$ incubation, whereas $\mathrm{MJ}$ and sucrose together elicited the accumulation of trans-resveratrol by 6 -fold after $6 \mathrm{~h}$ of incubation. In addition, MJ/sucrose treatment was found to produce 2-fold extra-cellular yield of resveratrol than MJ alone [55]. In a two-stage culture system, JA, along with mannitol, was found to maximize the accumulation (10.5 times) of resveratrol in callus culture because of synergistically enhanced metabolic production [31] (Table 1). However, the induction of resveratrol with JA was found to be consistent with the up-regulated expression of $P A L$ and STS, showing the transcriptional control of the synthesis of resveratrol [55].

Cyclodextrins, alone or in combination with MJ, were found to increase the extracellular accumulation (3- to 20-fold) of resveratrol in grapevine cell suspensions. However, the elicited accumulation was higher with MJ than that with cyclodextrins [56,57] (Table 1). The STS expression was found to be higher after $24 \mathrm{~h}$ of cyclodextrins treatment, whereas MJ incubated cells showed stable higher expression after $72 \mathrm{~h}$. Moreover, $P A L, C 4 H, 4 C L, C H S$ of the anthocyanins/isoflavonoids pathway were found to be stimulated by both the elicitors [56].

In another cell suspension culture, elicited accumulation of intracellular resveratrol with JA, SA, glucan (GLU), and chitosan (CHI) were found to be manifold, where the combined treatment of JA and GLU induced the extracellular accumulation of resveratrol by 10-fold (Figure 2) [58]. However, an industrial scale increased production of resveratrol $(2400 \mathrm{mg} / \mathrm{L})$ was obtained by the combined treatment of Amberlite XAD-7 resin, JA, and GLU [58]. SA was found to induce the resveratrol accumulation alone (2 times), but a negative effect of the combined use of SA and JA was observed on the accumulation of resveratrol, verifying the inhibitory effect of SA on the synthesis and signal transduction of JA [59] (Table 1).<smiles>OC[C@H]1O[C@@H](Oc2cc(O)cc(/C=C\c3ccc(O)cc3)c2)[C@H](O)[C@@H](O)[C@@H]1O</smiles><smiles>CC(C)=CC[C@@H](O)C1=CC(=O)c2c(O)ccc(O)c2C1=O</smiles>

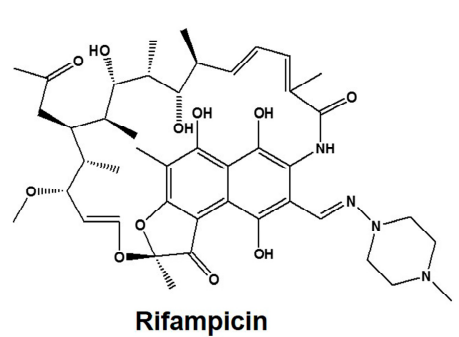<smiles>CC/C=C/C[C@H]1C(=O)C=C[C@@H]1CCCCCCCC(=O)O</smiles>

12-oxo-phytodienoic acid
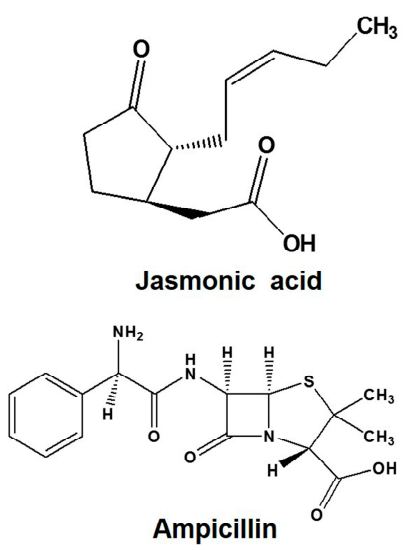

Ampicillin

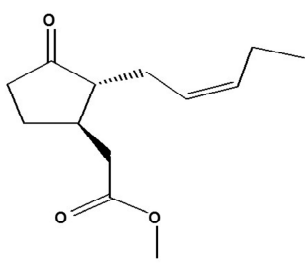

Methyl Jasmonate<smiles>CCOP(=O)(OC)OC</smiles>

Fosetylaluminium<smiles>O=C(O)c1ccccc1O</smiles>

Salicylic Acid

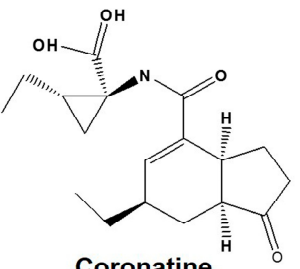

Coronatine
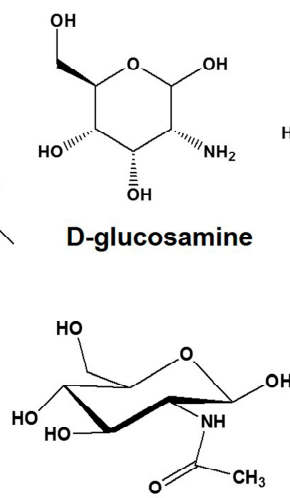

N-acetyl-D-glucosamine

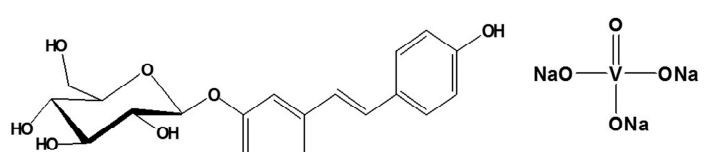

Na-orthovanadate

3-O-glucosyl-resveratrol

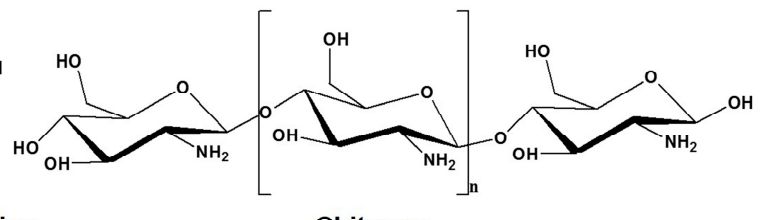

Chitosan

Figure 2. Molecular structure of different compounds or elicitors mentioned in this review. 
JA and coronatine (COR) were found to show an analogous increased accumulation style of resveratrol at $48 \mathrm{~h}$ and $96 \mathrm{~h}$ (1600 and $1900 \mu \mathrm{g} / \mathrm{g}$ DW), whereas 12-oxo-phytodienoic acid (OPDA) elicited stable amounts of resveratrol (2200 at $48 \mathrm{~h} \mathrm{\mu g} / \mathrm{g}$ DW). However, MJ was found to accumulate $40 \%, 50 \%$, and $60 \%$ more resveratrol over JA, COR, and OPDA, respectively [60] (Table 1, Figure 2). The maximum resveratrol synthesis and secretion in culture media were observed in cell suspension due to the synergistic activities of cyclodextrins and COR combined treatment, as compared to the individual treatment [61]. The PAL and STS genes were found to be highly expressed with COR. However, the induced amount of resveratrol was not detected in a spent medium, demonstrating that post-transcriptional or post-translational behavior may also regulate the expression of the genes [61].

A chitin derivative $\mathrm{CHI}$ was also found to increase the accumulation of intracellular resveratrol by 10.5-fold, which further increased with increasing concentration of $\mathrm{CHI}[58,62]$. In suspension culture of Vitis vinifera L. cv. Gamay Freaux, indanoyl-isoleucine, $N$-linolenoyl-L-glutamine, and insect saliva (from Manduca sexta larvae) considerably increased the accumulation of phenolic acids, especially 3-O-glucosyl-resveratrol, by 7.0-fold, relative to the control, after $24 \mathrm{~h}$ of treatment, especially with saliva [63]. On the contrary, cell cultures of $V$. vinifera (Barbera) treated with MJ, JA, SA, CHI, $\mathrm{N}$-acetyl-D-glucosamine, Na-orthovanadate, D-glucosamine, ampicillin, and rifampicin (Figure 2) were found to increase the level of resveratrol $[64,65]$. Similarly, MJ, CHI, and yeast extracts were also found to increase the accumulation of phenolic content in grape and wine [66]. Yeast cell contains b-1,3- and b-1,6-glucans, mannoproteins, lipid, sterol, and chitin where many of them act as elicitors along with triggering of plant defense [67]. However, accumulation of plant secondary metabolites and up-regulation of $P A L$ in cell cultures treated with yeast extracts justified its effects on resveratrol accumulation [68]. However, $\mathrm{CHI}$ alone was found to increase $63 \%$ endogenous accumulation of resveratrol after 4 days, along with the decrease of resveratrol release in culture media, as compared with the control [69] (Table 1). How CHI increased the accumulation of resveratrol is yet to be clearly understood. CHI was found to promote the stilbene pathway enzyme proteins, which can induce the de novo biosynthesis of resveratrol. In addition, the accumulation of resveratrol also depends on the concentration, molecular weight and degree of $\mathrm{N}$-acetylation of $\mathrm{CHI}[69,70]$. $\mathrm{CHI}$ was also found to induce the accumulation of six different STS protein spots in comparison with the control, whereas STS transcript was not observed in the northern blot analysis, ensuring that the up-regulation of STS occurred at the post-translational level and can induce PR proteins including chitinase, glucanase, and $P A L$ in grapes $[69,71,72]$.

\section{Induction of Resveratrol by UV Irradiation}

UV-C light range from 200 to $280 \mathrm{~nm}$ wavelength is a germicidal, non-ionizing radiation that has been extensively using to sterilize fresh fruits and vegetables to maintain their quality $[73,74]$. UV-C is also very popular in the field of enhancing the production of the stilbene resveratrol in grape berries and grape process products, including grape juice and wine.

Previously, the accumulation of resveratrol was undetectable or less detectable in healthy leaves of the grape vine, whereas 50-400 $\mu \mathrm{g} / \mathrm{g}$ (fresh weight, FW) elicited amount of resveratrol was recorded in UV (260-270 $\mathrm{nm})$ irradiated grape berries [23,25,75,76]. A long time (10-15 $\mathrm{min})$ exposure with short distance $(15 \mathrm{~cm})$ of UV-C irradiation source from the grape leaf was found to increase resveratrol accumulation from not detectable to $750 \mu \mathrm{g} / \mathrm{g}$ (FW) resveratrol, which persisted for the subsequent 2 days [77-79]. Mature Napoleon grapes treated with UV-B and UV-C for $30 \mathrm{~min}$ and stored at $0{ }^{\circ} \mathrm{C}$ for 10 days, followed by incubation at $15{ }^{\circ} \mathrm{C}$ for 5 days, induced the resveratrol accumulation by 3 and 2 times, respectively, whereas UV-C treatment alone was found to increase the accumulation in immature grape [80]. In an unripe shipment, Californian table grape showed 4 times increased accumulation of resveratrol due to UV irradiation, whereas degradation occurred with fully matured grapes [81]. Similarly, increased accumulation $(15.2 \mu \mathrm{g} / \mathrm{g}$ FW) of resveratrol was observed in young cluster of berries irradiated with UV-C for $6 \mathrm{~min}$, followed by $24 \mathrm{~h}$ of incubation [82] (Table 1). 
However, for higher accumulation of resveratrol, an optimization of UV irradiation treatment was done and also patented under the following conditions: distance of $40 \mathrm{~cm}$, irradiation time of $30 \mathrm{~s}$, source power of $500 \mathrm{~W}$, and storage time of 3 days; this resulted in 3.4 times higher resveratrol in Flame cultivar and 2315 times in Red Globe cultivar, compared to the untreated controls [83]. With the optimized protocol, increased concentrations ( 2.5 and 2 times) of resveratrol in grape, juice, and wine, respectively, were also observed $[84,85]$ (Table 1$)$.

Another optimization of UV-C irradiation was done and patented regarding the increased accumulation of resveratrol in fruit and vegetables with irradiation strength ranging from 30-510 W for less than $1 \mathrm{~min}$, followed by incubation in 2-4 days, resulting in 10.8-fold higher accumulation than that observed in the untreated control [18,86-88]. UV treatment for $610.2 \mathrm{~mJ} / \mathrm{cm}^{2}$, followed by storage at $0{ }^{\circ} \mathrm{C}$ resulted in increased accumulation of resveratrol by 7-8 times after 1 and 6 days in Gerbong grapes, respectively $[89,90]$ (Table 1 ).

UV-C irradiation, following $\mathrm{CHI}$ application in grape berry, was found to be more effective in inducing the accumulation of resveratrol (23.2 times) than UV irradiation alone (18.1 times), while CHI alone did not induce an accumulation of resveratrol [72]. UV-C irradiation of Botrytis cinerea inoculated grape berries was found to decrease the infection and lesion size due to the induction of resveratrol [91].

Appropriate maceration conditions $\left(2 \mathrm{~h}\right.$ at $45^{\circ} \mathrm{C}$ with $0.2 \%$ sodium metabisulfite $\left(\mathrm{Na}_{2} \mathrm{~S}_{2} \mathrm{O}_{5}\right)$ are urgent for the proper extraction and solubilization of the induced stilbene in grape juice and UV-C treated grape variety. Grape variety Superior, following proper maceration, resulted in 35 times more accumulations of resveratrol in juice without any negative impact on sensory properties [92] (Table 1).

A UV-B laser ( $302.1 \mathrm{~nm}$, ionizing wavelength) treatment for $45 \mathrm{~min}$ was found to induce 6-fold resveratrol, immediately after the irradiation, whereas $300 \mathrm{~nm}$ radiation (non-ionizing wavelength) resulted in negligible accumulation [93]. Previous studies showed that single UV-C photon irradiation was responsible for elicited biosynthesis of resveratrol by STS activity [94]. However, the maximum biosynthesis of resveratrol was reported in response to UV-irradiation in 260-270 nm, signifying that DNA acts as a photoreceptor and the phenylalanine-polymalonate pathway is the key to resveratrol biosynthesis [25]. However, a strong elicitation of resveratrol at $302.1 \mathrm{~nm}$ further demonstrates that two-photon absorption could offer sufficient energy for the activation of phenylalanine-polymalonate pathway instead of single photon excitation [95].

Induced accumulation of resveratrol in grape skin, in accordance with the expression of genes related to stilbene synthase (STS), phenylalanine ammonia-lyase (PAL), and chalcone synthase (CHS), was higher in Muscat Bailey A (1910 $\mu \mathrm{g} / \mathrm{g}$ FW) after $8 \mathrm{~h}$ of UV-C irradiation, as compared to the accumulation in other two varieties tested [96] (Table 1). A stage and time-dependent increase in STS protein over the course of 0-96 $\mathrm{h}$ after UV treatment was reported, where STS expression was induced within $6 \mathrm{~h}$ and reached a maximum after $18 \mathrm{~h}$ in 30 days after fruiting, DAF. Contrarily, maximum STS proteins were observed after 18, 48, and $96 \mathrm{~h}$ of UV treatment of 70, 90, and $120 \mathrm{DAF}$, respectively [12]. STS was found to be distributed in organs and tissues specifically, and the induction of resveratrol by UV-C was controlled at the transcriptional and translational level [12]. However, the increase in STS enzyme in response to UV was not only dependent on time but also dependent on the developmental stage of berries and incubation after UV irradiation. Moreover, the elicited STS enzymes are mostly present on the grape skin cell wall, secondary cell wall, and in minimum amounts in the chloroplast [97]. In addition, the expression of STS genes was found to be higher before veraison, followed by a decrease up to maturity [98]. A total of 22 STS genes showed increased expression following the treatment with UV-C, and VaSTS expression was revealed as an important factor for the accumulation of resveratrol. Up-regulation of $P A L$ with $C 4 H$ and $4 C L$ was found in response to UV-C treatment, along with the down-regulation of $C H S[99,100]$, proving that the competitive relationship between STS and CHS, in response to UV-C, may play a vital role in the accumulation of resveratrol in grape berries [90]. 


\section{Elicitation of Resveratrol Due to Ozone}

Ozone extends the shelf life of table grapes by preventing fruit decay, where it can be applied as pre-storage or storage room treatment in the form of fumigation or as ozonated water [101]. In addition, ozone is also found to stimulate the synthesis of resveratrol in storage conditions but not in consistent amount. In order to control fungal attack in storage, fumigation of ozone was applied and has been reported an increase of resveratrol level in grape berry skin comparable with UV-induced amount [102]. Comparable accumulation of resveratrol $(1250 \mathrm{mg} / 100 \mathrm{~g} \mathrm{FW})$ was also found with $3.88 \mathrm{~g} / \mathrm{h}$ treatment for $5 \mathrm{~h}$ and storage for 2 days, where the total stilbenoids produced were higher than those from the UV treatment [18]. By maintaining the standard atmospheric condition in storage at $15^{\circ} \mathrm{C}$ and application of 8 ppm ozone, around 3.14 times elicited accumulation of resveratrol over control was found in cv. Napoleon table grapes [103]. Later, with an intermittent ozone (2 ppm) treatment, rather than continuous treatment, for $12 \mathrm{~h} /$ day was found to increase the accumulation of resveratrol by $17 \%-55 \%$ over control, along with the reduction in the decay of stored grapes [104]. Further, elicited accumulation of resveratrol in $V$. vinifera callus cultures from the leaf with the fumigation of ozone was obtained after $24 \mathrm{~h}$ of the treatment [105] (Table 1). Increased PAL activity and a rapid induction of parts of the grapevine STS promoter, together with a P-GUS reporter gene in the transgenic tobacco plant, was observed after treatment with ozone $(0.1 \mu \mathrm{L} / \mathrm{L}, 12 \mathrm{~h})$, revealing the underlying mechanism of the resveratrol induction with ozone $[105,106]$. In the literature, there is little information on the production of resveratrol in response to ozone treatments directly on the plant. It has been recently published that resveratrol was not detected in the leaves of two cultivars San Giuseppe and Maturano after ozone fumigation [107]. Previously, a lower concentration of ozone in the form of ozonated water was found to act against microbial growth but did not induce the accumulation of resveratrol in stored grapes $[18,108]$. However, a higher ratio of ozone concentration to exposure time is needed for the induction of resveratrol, which might cause the reduction of the sensory properties of grape berries. Therefore, using this approach could be suitable for the production of resveratrol-enriched products rather than elicitation of resveratrol in table grapes.

\section{Induction of Resveratrol Due to Metal Salt}

Metallic salt acts as a signaling compound and salts of mercury or copper were found to induce the production of isoflavanoids, sesquiterpenes, and also stilbene in Veratrum grandiflorum [109]. A systemic fungicide "fosetylaluminum" contains aluminum chloride $\left(\mathrm{AlCl}_{3}\right.$, Figure 2) was used against downy mildew disease of grape to induce de novo synthesis of phytoalexin, and following $15 \mathrm{~h}$ of incubation, leaves showed bright fluorescence under UV (254 and $366 \mathrm{~nm}$ ) light, a typical characteristic of trans-resveratrol [25]. The fluorescence was detected (presence of resveratrol) in principal veins, followed by fine venation, and ultimately covered both the surface of the leaf representing the systemic nature of aluminum chloride. The abaxial surface was found to show fluorescence only after UV treatment for the synthesis of resveratrol [25,110]. All concentrations of $\mathrm{AlCl}_{3}$ (from 7 to $90 \mathrm{mM}$ ) were found to have the potential to elicit the amount of resveratrol in the leaves of Vitis rupestris, where marginal concentrations $(7 \mathrm{mM})$ were needed to obtain a phytoalexin signal in leaves [111]. Similarly, induced accumulation of resveratrol in grape leaves (5.2 times) and berry skin (1.5) were observed with $\mathrm{CaCl}_{2}$, where UV irradiation, in combination with $\mathrm{CaCl}_{2}$, accumulated 37.2 times higher resveratrol [19] (Table 1). Furthermore, inefficient or poorly efficient stilbene synthase gene expression with an application of $\mathrm{AlCl}_{3}$ and $\mathrm{CaCl}_{2}$ individually were found in relation to the induced accumulation of resveratrol $[19,94]$. UV irradiation combined with $\mathrm{CaCl}_{2}$ showed significant up-regulation of $P A L, 4 C L, C H 4$, and STS, parallel with the resveratrol accumulation, suggesting that $\mathrm{Ca}^{2+}$ may participate in the signal transduction pathway of UV-C-induced biosynthesis [19]. Pea treated with $\mathrm{CdCl}_{2}$ has been hypothesized to demonstrate a definite role of metallic salt in inducing the synthesis of phytoalexin [112]. 


\section{Induced Accumulation of Resveratrol Due to Pesticides}

Plant diseases are the vital reasons for the reduced yield of crops. Hence, farmers need to apply fungicides or pesticides to protect their crops. Phenolics, including resveratrol, were found to be induced by microbial infection, as well as UV irradiation [83]. Wine from cv. Campania treated with wettable sulfur (a fungicide and insecticide) showed an increased accumulation of trans-resveratrol by 1.6 times, as compared with the control [113]. Grapes treated with other pesticides (Quinoxyfen, Fenarimol, Penconazole, Dinocap) also resulted in higher amounts of trans-resveratrol accumulation over control [113]. The wines prepared from wettable sulfur treated grapes showed the highest amount (1.4 times) of trans-resveratrol, relative to the control [114] (Table 1). Furthermore, the wines showed varying degrees of resveratrol, resulting from several factors influencing the wine composition: vinification process (red or white), climatic conditions, different agronomical practices, and exposure of the vineyards to different atmospheric agents.

\section{Effect of Enological Practice for the Increased Amount of Resveratrol}

Grape skin shows high accumulation of resveratrol. Hence, maximum extraction of resveratrol occurred with long fermentation time [22]. Different processing techniques including maceration have great impacts on the improved extraction of resveratrol, ultimately leading to the increased resveratrol concentration in grape juice and wine. Maceration was found to increase the extraction of resveratrol in wines by 10-fold compared with just pressing a little for a very short time on grape skins. On the contrary, macerated wines contain up to 13-fold more resveratrol than non-macerated wines [22,115-117] (Table 1). Likewise, the maximum accumulation of resveratrol was also found in Merlot wine M12 up to 10 days of maceration with French Yeast and $\mathrm{SO}_{2}$ [117]. In addition, maceration time and type of yeast and concentration of $\mathrm{SO}_{2}$ were also found to be important factors influencing the concentration of resveratrol in wine [117].

\section{Induction of Resveratrol Due to Fertilizer}

Mineral nutrition not only affects the yield and quality of the plant but also plays a significant role in the resistance or susceptibility to disease by interfering with the biochemical mechanism. Nitrogen is an important nutrient for the synthesis of plant secondary metabolites such as alkaloids, anthocyanins, and shikonin (Figure 2) from cell suspension cultures [118]. Earlier, application of nitrogen in a hybrid grape variety Ga-58-30 and Fr 993-60 showed increased resistance to powdery and downy mildew disease with the elicited amount (4970 s.u.) of resveratrol in leaves [119]. Furthermore, increased accumulation of resveratrol was observed with high potassium, along with low levels of nitrogen, where high potassium levels could not diminish the negative effect of high level of nitrogen [120]. The basis of defense mechanism or the production of phytoalexin evolved at a low nitrogen level for the equilibrium between primary and secondary pathway, ensuring the movement of a large pool of the phenolics and alkaloids to the shikimate pathway [121]. For these reasons, nitrogen application in the vineyard has to be judicious in order to obtain a high yield of grapes, along with a maximum accumulation of resveratrol. A synchronized application of nitrogen with proper vegetative growth could be a better way to resolve the incompatible relationship of increased level of nitrogen with an accumulation of resveratrol [122]. However, harvested grapes kept for 6-15 h at room temperature in a vacuum chamber packed with nitrogen showed increased accumulation of resveratrol [123]. Recently, ammonium nitrate $\mathrm{NH}_{4} \mathrm{NO}_{3}$ as a source of nitrogen was found to elicit the accumulation of resveratrol at 14 th day by 5.6 -fold in cell culture [124] (Table 1). 
Table 1. Induced amount of resveratrol in grape skin, leaves, juice, wine, and cell/callus cultures by different external stimuli.

\begin{tabular}{|c|c|c|c|c|c|c|c|}
\hline & \multirow{2}{*}{ Eliciting Agent } & \multicolumn{5}{|c|}{ Induction of Resveratrol up to (by Fold/Amount) } & \multirow[t]{2}{*}{ References } \\
\hline & & Grape & Leaf & Juice & Wine & Cell/Callus Cultures & \\
\hline \multirow{5}{*}{ Biotic agents } & B. cinerea & 3.2 & 5 & - & little & - & {$[20-22,26-30]$} \\
\hline & P. viticola & 5 & - & - & - & - & [13] \\
\hline & R. stolonifer & 8.5 & - & - & - & - & {$[23]$} \\
\hline & F. oxysporum + mannitol & - & - & - & - & 6 & {$[31]$} \\
\hline & Bacillus + Botrytis & - & 16 & - & - & - & {$[27]$} \\
\hline \multirow{5}{*}{ Abiotic agent/Physical force } & LED & 8.4 & - & - & - & - & {$[41]$} \\
\hline & UV & 2315 & 750 & 35 & 2 & 2 & {$[18,23,25,75-90,92-96]$} \\
\hline & $\mathrm{UV}+\mathrm{CHI}$ & 23.2 & - & - & - & - & [72] \\
\hline & $\mathrm{UV}+\mathrm{CaCl}_{2}$ & 16.6 & 37.2 & - & - & - & [19] \\
\hline & Ozonization & 3.14 & - & - & - & 1.5 & [18,101-105] \\
\hline \multirow{13}{*}{ Elicitors/signaling molecules } & $\mathrm{JA} / \mathrm{MJ}$ & - & - & - & - & 20 & {$[54,55,57,58,64-66]$} \\
\hline & JA + Mannitol & - & - & - & - & 10.5 & [31] \\
\hline & $\mathrm{MJ}+$ Sucrose & - & - & - & - & 6 & [55] \\
\hline & MJ + GLU & - & - & - & - & 10 & {$[58,66]$} \\
\hline & SA & - & - & - & - & 2 & {$[58,59,64,66]$} \\
\hline & Cyclodextrins & - & - & - & - & 3 & [57] \\
\hline & Cyclodextrins + MJ & - & - & - & - & $>20$ & [56] \\
\hline & Amberlite XAD-7 + JA + GLU & - & - & - & - & $2400 \mu \mathrm{g} / \mathrm{g} \mathrm{dw}$ & [58] \\
\hline & COR & - & - & - & - & $1900 \mu \mathrm{g} / \mathrm{g} \mathrm{dw}$ & [60] \\
\hline & OPDA & - & - & - & - & $2200 \mu \mathrm{g} / \mathrm{g} \mathrm{dw}$ & {$[60]$} \\
\hline & $\mathrm{CHI}$ & - & - & - & - & $63 \%$ & {$[58,62,64,66,69]$} \\
\hline & $\mathrm{AlCl}_{3}$ (Fosetylaluminum) & - & 350 & - & - & - & [110] \\
\hline & $\mathrm{CaCl}_{2}$ & 1.5 & 5.2 & - & - & - & [19] \\
\hline \multirow{2}{*}{ Fertilizer } & Nitrogen & - & 5.6 & - & - & - & {$[118,121,123]$} \\
\hline & Potassium + Nitrogen & - & $>2$ & - & - & - & [119] \\
\hline \multirow{2}{*}{ Fungicides } & Wettable sulpher & - & - & - & 1.6 & - & {$[112,113]$} \\
\hline & Quinoxyfen, Fenarimol, Penconazole, Dinocap & - & - & - & 2.25 & - & [112] \\
\hline \multirow{2}{*}{ Others } & Enological practice & - & - & 13 & - & - & {$[22,114,115]$} \\
\hline & Maceration & - & - & - & 10 & - & {$[22,114-116]$} \\
\hline
\end{tabular}




\section{Conclusions and Future Prospects}

Consumers around the world are showing more interest in using natural herbal products instead of synthetic ones to treat various diseases. The demand of resveratrol is increasing due to its potential role in cardiovascular diseases, anti-cancer effects, and anti-aging effects. To meet the increasing demand, currently, resveratrol is marketed in the form of herbal or dietary complement as capsules, powders, and pills. However, consumers and nutritionists are continuously searching for the better supplements from natural sources in order to reduce the negative effect on human health. Most of the available resveratrol-enriched foodstuffs have originated from botanical sources. Along with resveratrol, botanical sources also provide derivatives, cofactors, and different phytonutrients, which may give the synergistic effect of the nutraceutical products. Several strategies for the biotic synthesis of resveratrol, including engineering of yeast, bacteria, or recombinant plants have been tried to ensure the consistent supply of resveratrol and its derivatives. However, continuous efforts are being made to find out better sources or strategies for the production of the higher amount of resveratrol. As grape skin is the most important source of resveratrol in red wine and juice, elicitation of resveratrol accumulation in grape skin can have practical applications. Hence, we summarize efforts to increase the accumulation of resveratrol in grapes.

Few plant species, including grape, peanuts, pine tree, and tomato produces resveratrol. However, grape contains more resveratrol than all other natural sources. Almost all the plant parts of grape including grape skin, stem, leaf, petiole, and root contain resveratrol. However, the maximum resveratrol is present in grape skin. As the major findings, UV treatment significantly increased the accumulation of resveratrol more than 2000-fold. Recently, US and LED exposure markedly induced the amount of resveratrol for about 8-fold in grape skin, which helped to produce resveratrol-enriched grape juice and wine. In addition, the combined treatment of UV with CHI, or other elicitors induced higher resveratrol concentration than by UV treatment alone. The amount of resveratrol-induced in cell suspension cultures, varied in response to different elicitors such as JA, SA, and COR. However, to meet the increasing demand of this compound, more effort should be taken to elicit higher accumulation of resveratrol in natural sources. To attain maximum level of resveratrol content, the application of various biotechnological strategies is important. Simultaneously, continuous searching of effective and economically viable elicitors and genes for microbes or plant transformation are also needed.

Currently, nutraceutical is the most promising market for resveratrol. As a food supplement, metabolic engineering of resveratrol in microbes could be the most effective way to meet the increasing demand. Resveratrol in the grape skin is induced by different external factors and might be the most important source to meet the increasing demand. Ultrasonication cleaner, along with tap water, is usually used to clean many fruits and vegetable to produce contamination-free produce along with induction of resveratrol in grapes and peanut $[43,47]$. US, along with UV and/or LED could be a significant way to increase the accumulation of resveratrol in grape skin. However, induced accumulation of resveratrol in the grape skin might have a significant practical implication in the grape juice and red wine industry.

Phytochemicals in plants can be abruptly increased by the genetic transformation of the plant with important genes [125] and could be a possible way to increase the accumulation of secondary metabolites, including resveratrol [125]. Furthermore, selection of bacterial strain could be the most important criterion for successful and practical applications of plant transformation techniques in order to accumulate maximum resveratrol.

Application of different combinations of elicitors known as inducers of plant secondary metabolites could be another strategy for the increased production of resveratrol in grape skin or in cell suspension culture along with US, LED, and/or UV. However, prior to the application of hormones or elicitors, their toxicological effect on human health should be tested. Moreover, establishing routine cell or tissue suspension cultures, selection of high-producing cell lines, and optimization of culture media could be a better route to enhanced resveratrol production. 
Acknowledgments: This work was carried out with the support of the Next-Generation Biogreen 21 Program (PJ011113), Rural Development Administration, Korea.

Author Contributions: Md. Mohidul Hasan and Hanhong Bae wrote the paper. All authors have read and approved the final manuscript.

Conflicts of Interest: The authors declare no conflict of interest.

\section{Abbreviations:}

\begin{tabular}{|c|c|}
\hline US & Ultrasonication \\
\hline UV & Ultra violet \\
\hline LED & Light-emitting diode \\
\hline$P A L$ & Phenylalanine ammonia lyase \\
\hline STS & Stilbene synthase \\
\hline$R S$ & Resveratrol synthase (Syn. STS) \\
\hline $\mathrm{C} 4 \mathrm{H}$ & Cinnamate-4-hydroxylase \\
\hline $4 C L$ & Coumaroyl-CoA ligase \\
\hline $\mathrm{CHS}$ & Chalcone synthase \\
\hline$T A L$ & Tyrosine ammonia-lyase \\
\hline STS1 & Stilbene synthase1 \\
\hline STS2 & Stilbene synthase 2 \\
\hline O-3-GT & 3-O-beta-glycosyltransferases \\
\hline JA & Jasmonic acid \\
\hline SA & Salicylic acid \\
\hline $\mathrm{CHI}$ & Chitosan \\
\hline MJ & Methyl jasmonate \\
\hline GLU & Glucan \\
\hline COR & Coronatine \\
\hline OPDA & 12-oxo-phytodienoic acid \\
\hline DAF & Days after fruiting \\
\hline $\mathrm{AlCl}_{3}$ & Aluminum chloride \\
\hline $\mathrm{CaCl}_{2}$ & Calcium chloride \\
\hline $\mathrm{CdCl}_{2}$ & Cadmium chloride \\
\hline $\mathrm{Na}_{2} \mathrm{~S}_{2} \mathrm{O}_{5}$ & Sodium metabisulfite \\
\hline FW & Fresh Weight \\
\hline
\end{tabular}

\section{References}

1. International Food Information Council Foundation. Sweet Weight Management Opportunities. Available online: http://www.foodinsight.org/ (accessed on 29 March 2011).

2. Thomasset, S.C.; Berry, D.P.; Garcea, G.; Marczylo, T.; Steward, W.P.; Gescher, A.J. Dietary polyphenolic phytochemicals. Promising cancer chemopreventive agents in human? A review of their clinical properties. Int. J. Cancer 2006, 120, 451-458. [CrossRef] [PubMed]

3. Renaud, S.; De Lorgeril, M. Wine, alcohol, platelets and the French Paradox for coronary heart disease. Lancet 1992, 339, 1523-1526. [CrossRef]

4. Jang, M.; Cai, L.; Udeani, G.O.; Slowing, K.V.; Thomas, C.F.; Beecher, C.W.; Fong, H.H.; Farnsworth, N.R.; Kinghorn, A.D.; Mehta, R.G.; et al. Cancer chemopreventive activity of resveratrol, a natural product derived from grapes. Science 1997, 10, 218-220. [CrossRef]

5. Howitz, K.T.; Bitterman, K.J.; Cohen, H.Y.; Lamming, D.W.; Lavu, S.; Wood, J.G. Small molecule activators of sirtuins extend Saccharomyces cerevisiae lifespan. Nature 2003, 425, 191-196. [CrossRef] [PubMed]

6. Baur, J.A.; Pearson, K.J.; Price, N.L.; Jamieson, H.A.; Lerin, C.; Kalra, A. Resveratrol improves health and survival of mice on a high-calorie diet. Nature 2006, 444, 337-342. [CrossRef] [PubMed]

7. Donnez, D.; Jeandet, P.; Clement, C.; Courot, E. Bioproduction of resveratrol and stilbene derivatives by plant cells and microorganisms. Trends Biotechnol. 2009, 27, 706-713. [CrossRef] [PubMed] 
8. Lanz, T.; Tropf, S.; Marner, F.J.; Schroder, J.; Schroder, G. The role of cysteines in polyketide synthases. Site-directed mutagenesis of resveratrol and chalcone synthases, two key enzymes in different plant-specific pathways. J. Biol. Chem. 1991, 266, 9971-9976. [PubMed]

9. Vannozzi, A.; Dry, I.B.; Fasoli, M.; Zenoni, S.; Lucchin, M. Genome-wide analysis of the grapevine stilbene synthase multigenic family: Genomic organization and expression profiles upon biotic and abiotic stresses. BMC Plant Biol. 2012, 12, 130. [CrossRef] [PubMed]

10. Holl, J.; Vannozzi, A.; Czemmel, S.; D'Onofrio, C.; Walker, A.R.; Rausch, T. The R2R3-MYB transcription factors MYB14 and MYB15 regulate stilbene biosynthesis in Vitis vinifera. Plant Cell 2013, 25, 4135-4149. [CrossRef] [PubMed]

11. Li, X.D.; Wu, B.H.; Wang, L.J.; Li, S.H. Extractable amounts of trans-resveratrol in seed and berry skin in Vitis evaluated at the germplasm level. J. Agric. Food Chem. 2006, 54, 8804-8811. [CrossRef] [PubMed]

12. Wang, W.; Tang, K.; Yang, H.R.; Wen, P.F.; Zhang, P.; Wang, H.L.; Huang, W.D. Distribution of resveratrol and stilbene synthase in young grape plants (Vitis vinifera L. cv. Cabernet Sauvignon) and the effect of UV-C on its accumulation. Plant Physiol. Biochem. 2010, 48, 142-152. [CrossRef] [PubMed]

13. Langcake, P. Disease resistance of Vitis spp. and the production of the stress metabolites resveratrol, $\varepsilon$-viniferin, $\alpha$-viniferin, and pterostilbene. Physiol. Plant Pathol. 1981, 18, 213-226. [CrossRef]

14. Dercks, W.; Creasy, L.L. The significance of stilbene phytoalexins in the Plasmopara viticola-grapevine interaction. Physiol. Mol. Plant Pathol. 1989, 34, 189-202. [CrossRef]

15. Schmidlin, L.; Poutaraud, A.; Claudel, P.; Mestre, P.; Prado, E.; Santos-Rosa, M. A stress-inducible resveratrol O-methyltransferase involved in the biosynthesis of pterostilbene in grapevine. Plant Physiol. 2008, 148, 1630-1639. [CrossRef] [PubMed]

16. Tassoni, A.; Fornale, S.; Franceschetti, M.; Musiani, F.; Michael, A.J.; Perry, B. Jasmonates and Na-orthovanadate promote resveratrol production in Vitis vinifera cv. Barbera cell cultures. New Phytol. 2005, 166, 895-905. [CrossRef] [PubMed]

17. Wen, P.F.; Chen, J.Y.; Kong, W.F.; Pan, Q.H.; Wan, S.B.; Huang, W.D. Salicylic acid induced the expression of phenylalanine ammonia-lyase gene in grape berry. Plant Sci. 2005, 169, 928-934. [CrossRef]

18. González-Barrio, R.; Beltrán, D.; Cantos, E.; Gil, M.I.; Espín, J.C.; Tomás-Barberán, F.A. Comparison of ozone and UV-C treatments on the postharvest stilbenoid monomer, dimer, and trimer induction in var. 'Superior' white table grapes. J. Agric. Food Chem. 2006, 54, 4222-4228. [CrossRef] [PubMed]

19. Wang, L.J.; Ma, L.; Xi, H.F.; Duan, W.; Wang, J.F.; Li, S.H. Individual and combined effects of $\mathrm{CaCl}_{2}$ and UV-C on the biosynthesis of resveratrols in grape leaves and berry skins. J. Agric. Food Chem. 2013, 61, 7135-7141. [CrossRef] [PubMed]

20. Bavaresco, L.; Pettegolli, D.; Cantu', E.; Fregoni, M.; Chiusa, G.; Trevisan, M. Elicitation and accumulation of stilbene phytoalexins in grapevine berries infected by Botrytis cinerea. Vitis 1997, 36, 77-83.

21. Langcake, P.; McCarthy, W.V. The relationship of resveratrol production to infection of grapevine leaves by Botrytis cinerea. Vitis 1979, 18, 244-253.

22. Jeandet, P.; Bessis, R.; Sbaghi, M.; Meunier, P. Production of the phytoalexin resveratrol by grapes as a response to Botrytis attack under natural conditions. J. Phytopathol. 1995, 143, 135-139. [CrossRef]

23. Sarig, P.; Zutkhi, Y.; Monjauze, A.; Lisker, N.; Ben-Arie, R. Phytoalexin elicitation in grape berries and their susceptibility to Rhizopus stolonifer. Physiol. Mol. Plant Pathol. 1997, 50, 337-347. [CrossRef]

24. Romero-Pe'rez, A.I.; Lamuela-Raventós, R.M.; Andrés-Lacueva, C.; De la Torre-Boronat, M.C. Method for the quantitative extraction of resveratrol and piceid isomers in grape berry skins. Effect of powdery mildew on the stilbene content. J. Agric. Food Chem. 2001, 49, 210-215. [CrossRef]

25. Langcake, P.; Pryce, R.J. The production of resveratrol by Vitis vinifera and other members of the Vitaceae as a response to infection or injury. Physiol. Plant Pathol. 1976, 9, 77-86. [CrossRef]

26. RoldaäN, A.; Palacios, V.; Caro, I.; PeäRez, L. Resveratrol content of Palomino fino grapes: Influence of vintage and fungal infection. J. Agric. Food Chem. 2003, 51, 1464-1468. [CrossRef] [PubMed]

27. Paul, B.; Chereyathmanjiyil, A.; Masih, I.; Chapuis, L.; Beno1^t, A. Biological control of Botrytis cinerea causing gray mould disease of grapevine and elicitation of stilbene phytoalexin (resveratrol) by a soil bacterium. FEMS Microbiol. Lett. 1998, 165, 65-70. [CrossRef]

28. Montero, C.; Cristescu, S.M.; Jiménez, J.B.; Orea, J.M.; Lintel Hekkert, S.T.; Harren, F.J.M.; González Ureń, A. Trans-resveratrol and grape disease resistance. A dynamical study by high-resolution laser-based techniques. Plant Physiol. 2003, 131, 129-138. [CrossRef] [PubMed] 
29. Nikfardjam, M.S.P.; László, G.; Dietrich, H. Resveratrol-derivatives and antioxidative capacity in wines made from botrytized grapes. Food Chem. 2006, 96, 74-79. [CrossRef]

30. Timperio, A.M.; D'Alessandro, A.; Fagioni, M.; Magro, P.; Zolla, L. Production of the phytoalexins trans-resveratrol and delta-viniferin in two economy-relevant grape cultivars upon infection with Botrytis cinerea in field conditions. Plant Physiol. Biochem. 2012, 50, 65-71. [CrossRef] [PubMed]

31. Mihai, R.; Cristina, S.; Helepciuc, F.; Brezeanu, A.; Stoian, G. Biotic and abiotic elicitors induce biosynthesis and accumulation of resveratrol with antitumoral activity in the long-term Vitis vinifera L. callus cultures. Rom. Biotechnol. Lett. 2011, 16, 6683-6689.

32. Feys, B.J.; Parker, J.E. Interplay of signaling pathways in plant disease resistance. Trends Genet. 2000, 16, 449-455. [CrossRef]

33. Ahn, S.Y.; Kim, S.A.; Cho, K.S.; Yun, H.K. Expression of genes related to flavonoid and stilbene synthesis as affected by signaling chemicals and Botrytis cinerea in grapevines. Biol. Plant. 2014, 58, 758-767. [CrossRef]

34. Shohael, A.M.; Ali, M.B.; Yu, K.W.; Hahn, E.J.; Islam, R.; Paek, K.Y. Effect of light on oxidative stress, secondary metabolites and induction of antioxidant enzymes in Eleutherococcus senticosus somatic embryos in bioreactor. Process Biochem. 2006, 41, 1179-1185. [CrossRef]

35. Downey, M.O.; Harvey, J.S.; Robinson, S.P. The effect of bunch shading on berry development and flavonoid accumulation in Shiraz grapes. Aust. J. Grape Wine Res. 2004, 10, 55-73. [CrossRef]

36. Johkan, M.; Shoji, K.; Goto, F.; Hashida, S.; Yoshihara, T. Blue light-emitting diode light irradiation of seedlings improves seedling quality and growth after transplanting in red leaf lettuce. Hortic. Sci. 2010, 45, 1809-1814.

37. Potrebko, I.; Resurreccion, A.V.A. Effect of ultraviolet doses in combined ultraviolet-ultrasound treatments on trans-resveratrol and trans-piceid contents in sliced peanut kernels. J. Agric. Food Chem. 2009, 57, 7750-7756. [CrossRef] [PubMed]

38. Ma, G.; Zhang, L.; Kato, M.; Yamawaki, K.; Kiriiwa, Y.; Yahata, M.; Ikoma, Y.; Matsumoto, H. Effect of blue and red LED light irradiation on $\beta$-cryptoxanthin accumulation in the flavedo of citrus fruits. J. Agric. Food Chem. 2012, 60, 197-201. [CrossRef] [PubMed]

39. Tuan, P.A.; Thwe, A.A.; Kim, Y.B.; Kim, J.K.; Kim, S.J.; Lee, S.; Chung, S.O.; Park, S.U. Effects of white, blue, and red lightemitting diodes on carotenoid biosynthetic gene expression levels and carotenoid accumulation in sprouts of tartary buckwheat (Fagopyrum tataricum Gaertn.). J. Agric. Food Chem. 2013, 61, 12356-12361. [CrossRef] [PubMed]

40. Heo, J.W.; Lee, C.W.; Chakrabarty, D.; Paek, K.Y. Growth responses of marigold and salvia bedding plants as affected by monochromic or mixture radiation provided by a light-emitting diode (LED). Plant Growth Regul. 2002, 38, 225-230. [CrossRef]

41. Ahn, S.Y.; Kim, S.A.; Choi, S.J.; Yun, H.K. Comparison of accumulation of stilbene compounds and stilbene related gene expression in two grape berries irradiated with different light sources. Hortic. Environ. Biotechnol. 2015, 56, 36-43. [CrossRef]

42. Zhou, B.; Wang, Y.; Zhan, Y.; Li, Y.; Kawabata, S. Chalcone synthase family genes have redundant roles in anthocyanin biosynthesis and in response to blue/UV-A light in turnip (Brassica rapa; Brassicaceae). Am. J. Bot. 2013, 100, 2458-2467. [CrossRef] [PubMed]

43. Lin, I.; Erel, D. Dynamic Ultrasonic Cleaning and Disinfecting Device and Method. U.S. Patent 5,113,881, 19 May 1992.

44. Hasan, M.M.; Baek, K.H. Induction of resveratrol biosynthesis in grape skin and leaves by ultrasonication treatment. Korean J. Hortic. Sci. Technol. 2013, 31, 496-502. [CrossRef]

45. Rudolf, J.R.; Resurreccion, A.V.A. Elicitation of resveratrol in peanut kernels by application of abiotic stresses. J. Agric. Food Chem. 2005, 53, 10186-10192. [CrossRef] [PubMed]

46. Sales, J.M.; Resurreccion, A.V.A. Maximising resveratrol and piceid contents in UV and ultrasound treated peanuts. Food Chem. 2009, 11, 7674-7680. [CrossRef]

47. Hasan, M.M.; Yun, H.K.; Kwak, E.J.; Baek, K.H. Preparation of resveratrol-enriched grape juice from ultrasonication treated grape fruits. Ultrason. Sonochem. 2014, 21, 729-734. [CrossRef] [PubMed]

48. Lin, L.; Wu, J.; Ho, K.P.; Qi, S. Ultrasound-induced physiological effects and secondary metabolite (saponin) production in Panax ginseng cell cultures. Ultrasound Med. Biol. 2001, 27, 1147-1152. [CrossRef]

49. Xiao, Y.M.; Wu, Q.; Cai, Y.; Lin, X.F. Ultrasound accelerated enzymatic synthesis of sugar esters in nonaqueous solvents. Carbohydr. Res. 2005, 340, 2097-2103. [CrossRef] [PubMed] 
50. Wu, J.; Lin, L. Ultrasound-induced stress responses of Panax ginseng cells: Enzymatic browning and phenolics production. Biotechnol. Prog. 2002, 18, 862-866. [CrossRef] [PubMed]

51. Soleas, G.J.; Diamandis, E.P.; Goldberg, D.M. Resveratrol: A molecule whose time has come? And gone? Clin. Biochem. 1997, 30, 91-113. [CrossRef]

52. Ahn, S.Y.; Kim, S.A.; Han, J.H.; Choi, S.J.; Yun, H.K. Induction of defense-related responses and suppression of grey mold in grapevines treated with defense response signaling molecules. J. Am. Pomol. Soc. 2013, 67, 104-116.

53. Jeandet, P.; Breuil, A.C.D.; Bessis, R.; Debord, S.; Sbaghi, M.; Adrian, M. Phytoalexins from the Vitaceae: Biosynthesis, phytoalexin gene expression in transgenic plants, antifungal activity, and metabolism. J. Agric. Food Chem. 2002, 50, 2731-2741. [CrossRef]

54. Krisa, S.; Larronde, F.; Budzinski, H.; Decendit, A.; Deffieux, G.; Michel, M.J. Stilbene production by Vitis vinifera cell suspension cultures: methyl jasmonate induction and ${ }^{13} \mathrm{C}$ biolabeling. J. Nat. Prod. 1999, 62, 1688-1690. [CrossRef]

55. Belhadj, A.; Telef, N.; Saigne, C.; Cluzet, S.; Barrieu, F.; Hamdi, S.; Mérillon, J.M. Effect of methyl jasmonate in combination with carbohydrates on gene expression of PR proteins, stilbene and anthocyanin accumulation in grapevine cell cultures. Plant Physiol. Biochem. 2008, 46, 493-499. [CrossRef] [PubMed]

56. Lijavetzky, D.; Almagro, L.; Belchi-Navarro, S.; Martínez-Zapater, J.M.; Bru, R.; Pedreño, M.A. Synergistic effect of methyljasmonate and cyclodextrin on stilbene biosynthesis pathway gene expression and resveratrol production in Monastrell grapevine cell cultures. BMC Res. Notes 2008, 1, 132. [CrossRef] [PubMed]

57. Belchí-Navarro, S.; Almagro, L.; Lijavetzky, D.; Bru, R.; Pedreño, M.A. Enhanced extracellular production of trans-resveratrol in Vitis vinifera suspension cultured cells by using cyclodextrins and methyljasmonate. Plant Cell Rep. 2012, 31, 81-89. [CrossRef] [PubMed]

58. Vuonga, T.V.; Francoa, C.; Zhang, W. Treatment strategies for high resveratrol induction in Vitis vinifera L. cell suspension culture. Biotechnol. Rep. 2014, 1-2, 15-21. [CrossRef]

59. Martinez, C.; Blanc, F.; Le Claire, E.; Besnard, O.; Nicole, M.; Baccou, J.C. Salicylic acid and ethylene pathways are differentially activated in melon cotyledons by active or heat-denatured cellulase from Trichoderma longibrachiatum. Plant Physiol. 2001, 127, 334-344. [CrossRef] [PubMed]

60. Taurino, M.; Ingrosso, I.; D’amico, L.; Domenico, S.D.; Nicoletti, I.; Corradini, D.; Santino, A.; Giovinazzo, G. Jasmonates elicit different sets of stilbenes in Vitis vinifera cv. Negramaro cell cultures. SpringerPlus 2015, 4, 49. [CrossRef] [PubMed]

61. Almagro, L.; Belchí-Navarro, S.; Martínez-Marquez, A.; Bru, R.; Pedrēno, M.A. Enhanced extracellular production of trans-resveratrol in Vitis vinifera suspension cultured cells by using cyclodextrins and coronatine. Plant Physiol. Biochem. 2015, 97, 361-367. [CrossRef] [PubMed]

62. Ferri, M.; Dipalo, S.C.F.; Bagni, N.; Tassoni, A. Chitosan elicits mono-glucosylated stilbene production and release in fed-batch bioreactor cultures of grape cells. Food Chem. 2011, 124, 1473-1479. [CrossRef]

63. Caia, Z.; Knorra, D.; Smetanskaa, I. Enhanced anthocyanins and resveratrol production in Vitis vinifera cell suspension culture by indanoyl-isoleucine, $N$-linolenoyl-L-glutamine and insect saliva. Enzym. Microb. Technol. 2012, 50, 29-34. [CrossRef] [PubMed]

64. Righetti, L.; Franceschetti, M.; Ferri, M.; Tassoni, A.; Bagni, N. Resveratrol production in Vitis vinifera cell suspensions treated with several elicitors. Carpologia 2007, 60, 169-171.

65. Santamaria, A.R.; Mulinacci, N.; Valletta, A.; Innocenti, M.; Pasqua, G. Effects of elicitors on the production of resveratrol and viniferins in cell cultures of Vitis vinifera L. cv Italia. J. Agric. Food Chem. 2011, 59, 9094-9101. [CrossRef] [PubMed]

66. Portu, J.; López, R.; Baroja, E.; Santamaría, P.; Garde-Cerdán, T. Improvement of grape and wine phenolic content by foliar application to grapevine of three different elicitors: Methyl jasmonate, chitosan, and yeast extract. Food Chem. 2016, 201, 213-221. [CrossRef] [PubMed]

67. Keptayen, J.C.; Van Den Ende, H.; Klis, F.M. The contribution of cell wall proteins to the organization of the yeast cell wall. Biochim. Biophys. Acta 1999, 1426, 373-383.

68. Peltonen, S.; Mannonen, L.; Karjalainen, R. Elicitor-induced changes of phenylalanine ammonia-lyase activity in barley cell suspension cultures. Plant Cell Tissue Org. 1997, 50, 185-193. [CrossRef]

69. Ferri, M.; Tassoni, A.; Franceschetti, M.; Righetti, L.; Naldrett, M.J.; Bagni, N. Chitosan treatment induces changes of protein expression profile and stilbene distribution in Vitis vinifera cell suspensions. Proteomics 2009, 9, 610-624. [CrossRef] [PubMed] 
70. Aziz, A.; Trotel-Aziz, P.; Dhuicq, L.; Jeandet, P.; Couderchet, M.; Fernet, G. Chitosan oligomers and copper sulfate induce grapevine defense reactions and resistance to gray mold and downy mildew. Phytopathology 2006, 96, 1188-1194. [CrossRef] [PubMed]

71. Ghaouth, E.A.; Wilson, C.L.; Callahan, A.M. Induction of chitinase, $\beta-1,3$ glucanase, and phenylalanine ammonia-lyase in peach fruit by UV-C treatment. Phytopathology 2003, 93, 349-355. [CrossRef] [PubMed]

72. Romanazzi, G.; Gabler, F.M.; Smilanick, J.L. Preharvest chitosan and postharvest UV irradiation treatments suppress gray mold of table grapes. Plant Dis. 2006, 90, 445-450. [CrossRef]

73. Bintsis, T.; Litopoulou-Tzanetaki, E.; Robinson, R.K. Existing and potential applications of ultraviolet light in food industry-A critical review. J. Sci. Food Agric. 2000, 80, 637-645. [CrossRef]

74. Yaun, B.R.; Summer, S.S.; Eifert, J.D.; Marcy, J.E. Inhibition of pathogens on fresh produce by ultraviolet energy. Int. J. Food Microbiol. 2004, 90, 1-8. [CrossRef]

75. Langcake, P.; Pryce, R.J. The production of resveratrol and the viniferins by grapevines in response to ultraviolet irradiation. Phytochemistry 1977, 16, 1193-1196. [CrossRef]

76. Jeandet, P.; Bessis, R.; Gautheron, B. The production of resveratrol (3,5,4'-trihydroxystilbene) by grape berries in different developmental stages. Am. J. Enol. Vitic. 1991, 42, 41-46.

77. Douillet-Breuil, A.C.; Jeandet, P.; Adrian, M.; Bessis, R. Changes in the phytoalexin content of various Vitis spp. in response to UV-C elicitation. J. Agric. Food Chem. 1999, 47, 4456-4461. [CrossRef] [PubMed]

78. Adrian, M.; Jeandet, P.; Douillet-Breuil, A.C.; Tesson, L.; Bessis, R. Stilbene content of mature Vitis vinifera berries in response to UV-C elicitation. J. Agric. Food Chem. 2000, 48, 6103-6105. [CrossRef] [PubMed]

79. Versari, A.; Parpinello, G.P.; Tornielli, G.B.; Ferrarini, R.; Giulivo, C. Stilbene compounds and stilbene synthase expression during ripening, wilting, and UV treatment in grape cv. Corvina. J. Agric. Food Chem. 2001, 49, 5531-5536. [CrossRef] [PubMed]

80. Cantos, E.; Garcia-Viguera, C.; De Pascual-Teresa, S.; Tomas-Barberan, F.A. Effect of postharvest ultraviolet irradiation on resveratrol and other phenolics of cv. Napoleon table grapes. J. Agric. Food Chem. 2000, 48, 4606-4612. [CrossRef] [PubMed]

81. Moriartry, J.M.; Harmon, R.; Weston, L.A.; Bessis, R.; Breuil, A.C.; Adrian, M.; Jeandet, P. Resveratrol content of two Californian table grape cultivars. Vitis 2001, 40, 43-44.

82. Petit, A.N.; Baillieul, F.; Vaillant-Gaveau, N.; Jacquens, L.; Conreux, A.; Jeandet, P.; Clement, C.; Fontaine, F. Low responsiveness of grapevine flowers and berries at fruit set to UV-C irradiation. J. Exp. Bot. 2009, 60, 1155-1162. [CrossRef] [PubMed]

83. Cantos, E.; Espin, J.C.; Tomas-Barberan, F.A. Postharvest stilbene-enrichment of red and white table grape varieties using UV-C irradiation pulses. J. Agric. Food Chem. 2002, 50, 6322-6329. [CrossRef] [PubMed]

84. Cantos, E.; Tomas-Barberan, F.A.; Martinez, A.; Espin, J.C. Differential stilbene induction susceptibility of seven red wine grape varieties upon post-harvest UV-C irradiation. Eur. Food Res. Technol. 2003, 217, 253-258. [CrossRef]

85. Cantos, E.; Espin, J.C.; Fernandez, M.J.; Oliva, J.; Tomas-Barberan, F.A. Postharvest UV-C-irradiated grapes as a potential source for producing stilbene-enriched red wines. J. Agric. Food Chem. 2003, 51, 1208-1214. [CrossRef] [PubMed]

86. Tomás-Barberán, F.; Espín, J.C.; Cantos, V.E. Postharvest Treatment of Fruits and Vegetables Using Ultra Violet Irradiation Pulses. Patent WO/2002/085137, 31 October 2002.

87. González-Barrio, R.; Salmenkallio-Marttila, M.; Tomás-Barberán, F.A.; Cantos, E.; Espín, J.C. Etiology of UV-C-induced browning in var. Superior white table grapes. J. Agric. Food Chem. 2005, 53, 5990-5996. [CrossRef] [PubMed]

88. Guerrero, R.F.; Puertas, B.; Fernández, M.I.; Palma, M.; Cantos-Villar, E. Induction of stilbenes in grapes by UV-C: Comparison of different subspecies of Vitis. Innov. Food Sci. Emerg. Technol. 2010, 11, 231-238. [CrossRef]

89. Cho, Y.J.; Kim, N.; Kim, C.T.; Maeng, J.S.; Pyee, J. Quantitative evaluation of resveratrol enrichment induced by UV stimulus in harvested grapes. Food Sci. Biotechnol. 2012, 21, 597-601. [CrossRef]

90. Yin, X.; Singer, S.D.; Qiao, H.; Liu, Y.; Jiao, C.; Wang, H.; Li, Z.; Fei, Z.; Wang, Y.; Fan, C.; et al. Insights into the mechanisms underlying ultraviolet-C induced resveratrol metabolism in grapevine (V. amurensis Rupr.) cv. “Tonghua-3". Front. Plant Sci. 2016, 7, 1-16. [CrossRef] [PubMed]

91. Nigro, F.; Ippolito, A.; Lima, G. Use of UV-C light to reduce Botrytis storage rot of table grapes. Postharvest Biol. Technol. 1998, 13, 171-181. [CrossRef] 
92. González-Barrio, R.; Vidal-Guevara, M.L.; Tomás-Barberán, F.A.; Espín, J.C. Preparation of a resveratrolenriched grape juice based on ultraviolet C-treated berries. Innov. Food Sci. Emerg. Technol. 2009, 10, 374-382. [CrossRef]

93. Jiménez Sánchez, J.B.; Corral, C.E.; Orea, J.M.; Delgado, S.M.J.; Ureña, G.A. Elicitation of trans-resveratrol by laser resonant irradiation of table grapes. Appl. Phys. B 2007, 87, 559-563. [CrossRef]

94. Borie, B.; Jeandet, P.; Parize, A.; Bessis, R.; Adrian, M. Resveratrol and stilbene synthase mRNA production in grapevine leaves treated with biotic and abiotic phytoalexin elicitors. Am. J. Enol. Vitic. 2004, 55, 60-64.

95. Gonzálvez, A.G.; Jiménez, J.B.; Ureña, Á.G. Fruit-enhanced resistance to microbial infection induced by selective laser excitation. J. Spectrosc. 2013, 2013, 789159. [CrossRef]

96. Takayanagi, T.; Okuda, T.; Mine, Y.; Yokotsuka, K. Induction of resveratrol biosynthesis in skins of three grape cultivars by ultraviolet irradiation. J. Jpn. Soc. Hortic. Sci. 2004, 73, 193-199. [CrossRef]

97. Pan, Q.H.; Wang, L.; Li, J.M. Amounts and subcellular localization of stilbene synthase in response of grape berries to UV irradiation. Plant Sci. 2009, 176, 360-366. [CrossRef]

98. Wang, J.F.; Maa, L.; Xi, H.F.; Wang, L.J.; Li, S.H. Resveratrol synthesis under natural conditions and after UV-C irradiation in berry skin is associated with berry development stages in 'Beihong' (V. vinifera $\times$ V. amurensis). Food Chem. 2015, 168, 430-438. [CrossRef] [PubMed]

99. Xi, H.; Ma, L.; Liu, G.; Wang, N.; Wang, J.; Wang, L. Transcriptomic analysis of grape (Vitis vinifera L.) leaves after exposure to ultraviolet C irradiation. PLoS ONE 2014, 9, e113772. [CrossRef] [PubMed]

100. Suzuki, M.; Nakabayashi, R.; Ogata, Y.; Sakurai, N.; Tokimatsu, T.; Goto, S. Multi omics in grape berry skin revealed specific induction of stilbene synthetic pathway by UV-C irradiation. Plant Physiol. 2015, 168, 47-59. [CrossRef] [PubMed]

101. Palou, L.; Crisosto, C.H.; Smilanick, J.L.; Adaskaveg, J.E.; Zoffoli, J.P. Effects of continuous 0.3 ppm ozone exposure on decay development and physiological responses of peaches and table grapes in cold storage. Posthavest Biol. Technol. 2002, 24, 39-48. [CrossRef]

102. Sarig, P.; Zahavi, T.; Zutkhi, Y.; Yannai, S.; Lisker, N.; Ben-Arie, R. Ozone for control of post-harvest decay of table grapes caused by Rhizopus stolonifer. Physiol. Mol. Plant Pathol. 1996, 48, 403-415. [CrossRef]

103. Artés-Herna'ndez, F.; Artés, F.; Toma’s-Barbera'n, F.A. Quality and enhancement of bioactive phenolics in cv. Napoleon table grapes exposed to different postharvest gaseous treatments. J. Agric. Food Chem. 2003, 51, 5290-5295. [CrossRef] [PubMed]

104. Cayuela, J.A.; Vázquez, A.; Pérez, A.G.; García, J.M. Control of table grapes postharvest decay by ozone treatment and resveratrol induction. Food Sci. Technol. Int. 2009, 15, 495-502. [CrossRef]

105. Sgarbi, E.; Baroni Fornasicro, R.; Lins, A.A.P. Phenol metabolism is differentially affected by ozone in two cell lines from grape (Vitis vinifera L.) leaf. Plant Sci. 2003, 165, 951-957. [CrossRef]

106. Grimmig, B.; Schubert, R.; Fischer, R.; Hain, R.; Schreie, P.H.; Betz, C.; Langebartels, C.; Ernst, D.; Sandermann, J.H. Ozone-and ethylene-induced regulation of a grapevine resveratrol synthase promoter in transgenic tobacco. Acta Physiol. Plant. 1997, 19, 467-474. [CrossRef]

107. Valletta, A.; Salvatori, E.; Santamaria, A.R.; Nicoletti, M.; Toniolo, C.; Caboni, E.; Bernardini, A.; Pasqua, G.; Manes, F. Ecophysiological and phytochemical response to ozone of wine grape cultivars of Vitis vinifera $\mathrm{L}$. Nat. Prod. Res. 2016, 30, 2514-2522. [CrossRef] [PubMed]

108. Beltŕan, D.; Selma, M.V.; Tudela, J.A.; Gil, M.I. Effect of different sanitizers on microbial and sensory quality of fresh-cut potato strips stored under modified atmosphere or vacuum packaging. Postharvest Biol. Technol. 2005, 37, 37-46. [CrossRef]

109. Hanawa, F.; Tahara, S.; Mizutani, J. Antifungal stress compounds from Veratrum grandiflorum leaves treated with cupric chloride. Phytochemistry 1992, 31, 3005-3007. [CrossRef]

110. Pool, R.M.; Creasy, L.L.; Frackelton, A.S. Resveratrol and the viniferins, their application to screening for disease resistance in grape breeding programs. Vitis 1981, 20, 136-145.

111. Adrian, M.; Jeandet, P.; Bessis, R.; Joubert, J.M. Induction of phytoalexin (resveratrol) synthesis in grapevine leaves treated with aluminum chloride $\left(\mathrm{AlCl}_{3}\right)$. J. Agric. Food Chem. 1996, 44, 1979-1981. [CrossRef]

112. Loschke, D.C.; Hadwiger, L.A.; Wagoner, W. Comparison of mRNA populations coding for phenylalanine ammonia lyase and other peptides from pea tissue treated with biotic and abiotic inducers. Physiol. Plant Pathol. 1983, 23, 163-173. [CrossRef] 
113. Dugo, G.; Saitta, M.; Giuffrida, D.; Vilasi, F.; LA Torre, G.L. Determination of resveratrol and other phenolic compounds in experimental wines from grapes subjected to different pesticide treatments. Ital. J. Food Sci. 2004, 3, 16-20.

114. Dugo, G.; Bambara, G.; Salvo, F.; Saitta, M.; Lo Curto, S. Contenuto di resveratrolo in vini rossi da uve alloctone e autoctone prodotte in Sicilia. Inst. Res. Inf. Syst. 2000, 12, 79.

115. Pezet, R.; Cuenat, P. Resveratrol in wine: Extraction from skin during fermentation and post-fermentation standing of must from Gamay grapes. Am. J. Enol. Vitic. 1996, 47, 287-290.

116. Vrhovsek, U.; Wendelin, S.; Eder, R. Effects of various vinification techniques on the concentration of cis- and trans-resveratrol and resveratrol glucoside isomers in wine. Am. J. Enol. Vitic. 1997, 48, 214-219.

117. Kostadinović, S.; Wilkens, A.; Stefova, M.; Ivanova, V.; Vojnoski, B.; Mirhosseini, H.; Winterhalter, P. Stilbene levels and antioxidant activity of Vranec and Merlot wines from Macedonia: Effect of variety and enological practices. Food Chem. 2012, 135, 3003-3009. [CrossRef] [PubMed]

118. Sakuta, M.; Takagi, T.; Komamine, A. Effects of nitrogen source on betacyanin accumulation and growth in suspension cultures of Phytolacca americana. Physiol. Plant. 1987, 71, 459-463. [CrossRef]

119. Bavaresco, L.; Eibach, R. Investigations of the influence of $\mathrm{N}$ fertilizer on resistance to powdery mildew (Oidium tuckeri), downy mildew (Plasmopara viticola) and on phytoalexins synthesis in different grapevine varieties. Vitis 1987, 26, 192-200.

120. Bavaresco, L.; Fregoni, M.; Petegolli, D. Effect of nitrogen and potassium fertilizer on induced resveratrol synthesis in two grapevine genotypes. Vitis 1994, 33, 175-176.

121. Graham, R.D. Effects of nutrient stress on susceptibility of plants to disease with particular reference to the trace elements. Adv. Bot. Res. 1983, 10, 221-276.

122. Bavaresco, L.; Pezzutto, S.; Ragga, A.; Ferrari, F.; Trevisan, M. Effect of nitrogen supply on trans-resveratrol concentration in berries of Vitis Vinifera L. cv. Cabernet Sauvignon. Vitis 2001, 40, 229-230.

123. Jiménez, J.B.; Orea, J.M.; González-Ureña, A.; Escribano, P.; López de la Osa, P.; Guadarrama, A. Short anoxic treatments to enhance trans-resveratrol content in grapes and wine. Eur. Food Res. Technol. 2007, 224, 373-378. [CrossRef]

124. Sae-Lee, N.; Kerdchoechuen, O.; Laohakunjit, N. Enhancement of phenolics, resveratrol and antioxidant activity by nitrogen enrichment in cell suspension culture of Vitis vinifera. Molecules 2014, 19, 7901-7912. [CrossRef] [PubMed]

125. Kiselev, K.V. Perspectives for production and application of resveratrol. Appl. Microbiol. Biotechnol. 2011, 90, 417-425. [CrossRef] [PubMed]

(C) 2017 by the authors; licensee MDPI, Basel, Switzerland. This article is an open access article distributed under the terms and conditions of the Creative Commons Attribution (CC BY) license (http://creativecommons.org/licenses/by/4.0/). 